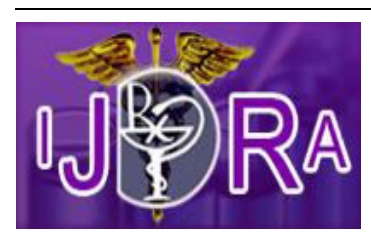

Available online on 15 June 2018 at http://ijdra.com/index.php/journal

International Journal of Drug Regulatory Affairs

Open Access to Pharmaceutical and Medical Research

(C) 2013-18, Publisher and Licensee IJDRA.

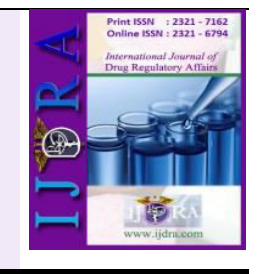

Review Article

Open

Access

\title{
Regulatory requirement for the approval of Generic Drug in Cambodia as per ASEAN Common Technical Dossier (ACTD)
}

\author{
Ravish Patel*, Amit Patel, Tejasvini Gohil \\ Ramanbhai Patel College of Pharmacy, Charotar University of Science and Technology, Changa-388421, Gujarat, India
}

\begin{abstract}
Drug approval process differs from one country to another country. In some countries only single body regulates the drug as well as responsible for all regulatory work which is a challenging task for the pharmaceutical companies to prepare single dossier that can be simultaneously submitted in many countries for approval. In all countries there is a similar characteristic in regulatory environment but there is a difference in their registration requirements. The purpose of this study is to give a comparative overview on generic drug market regulation in ASEAN Countries Cambodia and Malaysia. The aim of study is to facilitate proper knowledge regarding main critical issues, differences as well as similarities of related drug regulation. There is a different requirement for registration of generic product in each regulatory system but also comprises of some similar outline that includes some common rules. These are variances and regulatory hurdles such as Number of batches for submission in dossier, stability conditions, registration of product, analysis, bioequivalence and clinical study requirement. ASEAN countries for generic drug product approval ACTD submitted to country specific authority. For solid oral dosage forms as per ASEAN guideline there are 4 parts have to be submitted. Part I contains Administrative requirements which is not a part of common technical document. Part II is Quality contains 3 sections that are a) Table of Content b) Quality overall Summary c) Body of data. Part III contains Non clinical. Part IV contains Clinical data. For the generic drug product Part III and Part IV is not required.
\end{abstract}

Keywords: ASEAN Common Technical Document (ACTD), Regulatory Requirement, Cambodia, Malaysia

Article Info: Received 24 May, 2018; Review Completed 10 June 2018; Accepted 11 June 2018

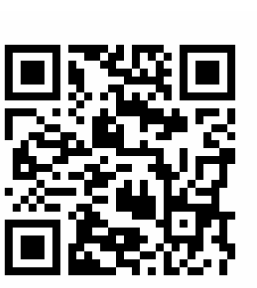

Cite this article as:

Patel R, Patel A, Gohil T. Regulatory requirement for the approval of Generic Drug in Cambodia as per ASEAN Common Technical Dossier (ACTD). International Journal of Drug Regulatory Affairs [Internet]. 15 Jun.2018 [cited 15 Jun. 2018]; 6(2):67-71. Available from: http://ijdra.com/index.php/journal/article/view/245

DOI: $10.22270 /$ ijdra.v6i2.245

*Corresponding author. Tel.: +91- 9924659216;

E-mail address: ravishpatel.ph@charusat.ac.in (R. Patel).

\section{Introduction}

\subsection{Introduction to ASEAN Countries}

ASEAN consultative committee on Safety and Quality (ACCSQ) developed the Association of South East Asian Nation (ASEAN) (1) on 8th August 1967 in Bangkok. The ASEAN Common Technical Document (ACTD) (2) is a guideline and the common format for the preparation of a well-structured Common Technical Dossier (CTD) application that are to be submitted to ASEAN regulatory authorities for the registration of pharmaceuticals product for human use. There are 10 member states in ASEAN countries that include Singapore, Malaysia, Indonesia, Vietnam, Thailand, Cambodia, Myanmar, Philippines, Brunei, Laos (1). These countries follow ACTD Format for the registration of pharmaceutical products. ACTD is divided into four Part I, (Administrative data) Part II (Quality) Part III
(Overview summary study report) Part III (Clinical Data). Figure 1 signifies ACTD guidelines.

\subsection{Introduction to Cambodia}

The drug registration process started in 1994. Department of Drugs and Food (DDF) (3) is the regulatory agency under the Ministry of Health. It is responsible for the efficacy, safety, quality of drug, efficacy of food and cosmetics.

\subsection{Introduction to Malaysia}

The regulatory body of Malaysia is National Pharmaceutical Regulatory Agency (NPRA) (4), formerly known as the National Pharmaceutical Control Bureau (BPFK), is located at Kuala Lumpur under the quality control activity of pharmacy and supply programme. This regulatory body was implemented with an aim to implement quality control on pharmaceutical products. 
According to Malaysia country a generic medicine can be defined as a pharmaceutical product that is no longer protected by a patent $\&$ which can be copied by other company. It may be marketed either under its own brand or as an unbranded product.

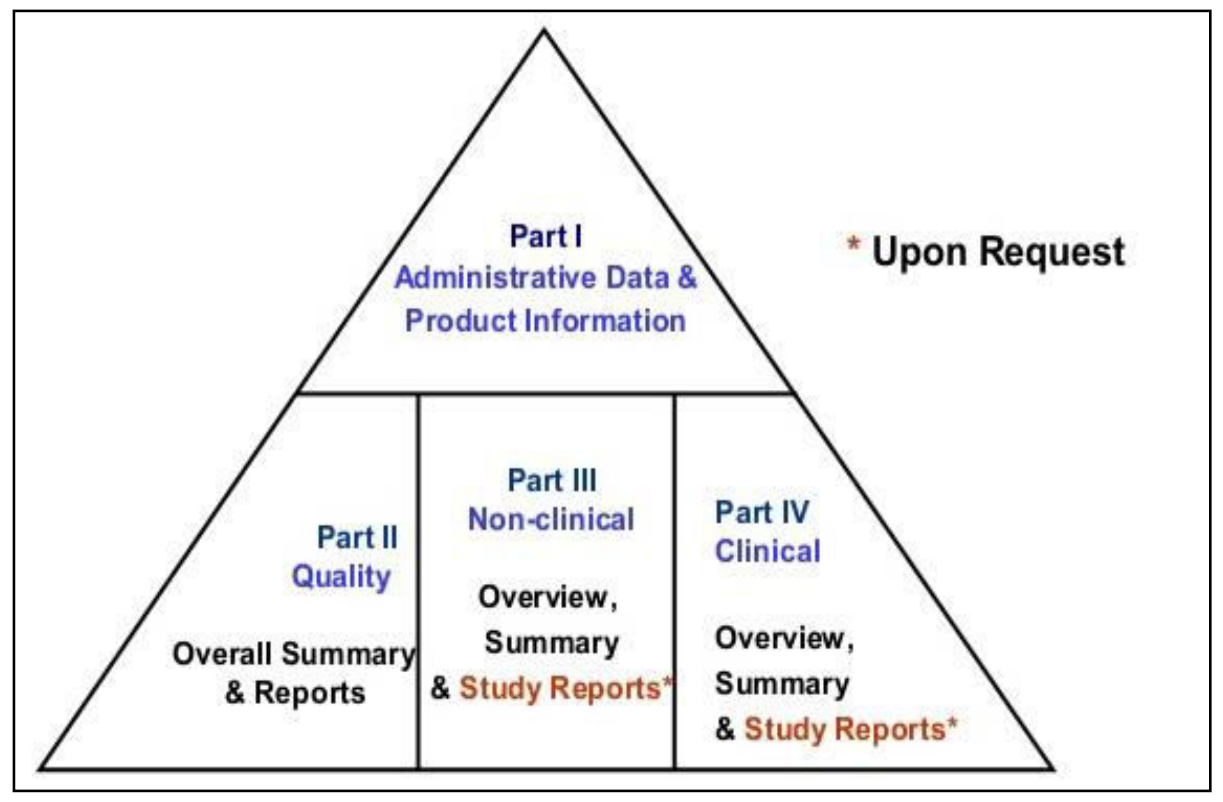

Figure 1. Diagrammatic explanation of ACTD

\section{Discussion}

In this section study of registration requirements for generic pharmaceutical product of selected countries was carried out and compared to understand the critical aspect of generic drug product data requirements.
Table 1 shows comparison of registration requirements for generic pharmaceutical product in Cambodia and Malaysia.

Table 1 Comparison of registration requirements $(3,4)$

\begin{tabular}{|c|c|c|}
\hline PARAMETERS & COMBODIA & MALAYSIA \\
\hline & Department of Drugs and Focd & $\begin{array}{c}\text { MINISTRY OF HEALTH } \\
\text { MALAYSIA }\end{array}$ \\
\hline Regulatory Authority & $\begin{array}{l}\text { Department of Drugs and Food under, } \\
\text { Ministry of Health }\end{array}$ & $\begin{array}{l}\text { National Pharmaceutical Control Bureau } \\
\text { (NPCB) }\end{array}$ \\
\hline $\begin{array}{l}\text { Regulatory Guidelines } \\
\text { Administrative Information }\end{array}$ & Follows ACTD Format & Follows ACTD Format \\
\hline Cover letter & Not Required & Not Required \\
\hline Application Form & Required & Required BPFK 438.1 for generic medicine \\
\hline Patient Information Leaflet & $\begin{array}{l}\text { Required compulsory for self- } \\
\text { administered drug it should be in English } \\
\text { \& Combodian Language (Khmer) }\end{array}$ & $\begin{array}{l}\text { Required compulsory for self-administered } \\
\text { drug }\end{array}$ \\
\hline $\begin{array}{l}\text { Summary of Product } \\
\text { Characteristics (SmPC) }\end{array}$ & Applicable & Applicable \\
\hline Label & $\begin{array}{l}\text { Required, must be in English and } \\
\text { Combodian Language (Khmer) }\end{array}$ & $\begin{array}{l}\text { Required, must be in English and Bahasa } \\
\text { Malaysia }\end{array}$ \\
\hline Package insert & $\begin{array}{l}\text { Required, must be in English and } \\
\text { Combodian Language (Khmer) }\end{array}$ & $\begin{array}{l}\text { Required, must be in English and Bahasa } \\
\text { Malaysia }\end{array}$ \\
\hline Fee & No fees required & $\begin{array}{l}\text { Single API- } 2200.00 \mathrm{RM} \\
\text { Two/more API- } 3000.00 \mathrm{RM}\end{array}$ \\
\hline Information about experts & No specific requirement & No specific requirement \\
\hline
\end{tabular}




\section{Certificate of Suitability \\ with European \\ Pharmacopeia (CEP) \\ GMP certificate}

\section{Free sale certificate \\ Certificate of pharmaceutical product \\ Letter of Authorization \\ Environmental Risk \\ assessment \\ Third Party Agreement}

Foreign regulatory status

Bio waiver request

\section{Technical Information \\ Drug Master File}

Batch Manufacturing

Record

In process quality Control

\section{Process Validation}

Raw material Specification

Raw material analytical process

Analytical Method

Validation

Finished Product

Specifications

Finished Product

Analytical Process

Analytical Method

Validation (FP)

Batch Analysis

Justification of

Specifications

Reference Standard

Container Closure system

Stability Protocol

Climatic Zone

Stability Number of

batches

\section{Stability Data}

Regional Information

Non clinical data

Clinical data
No specific requirement

Required as per WHO \&GMP guidelines

Not required

Not required

Required

No specific Requirement

Required with detail information about the supplier

Not Required

All bioequivalence study of product is required

Required as per ACTD format

Complete information of Commercial batches is required

Details of $I P Q C$ and specifications for quality assurance of the product is required

Required for 3 consecutive batches

Specifications and test methods for raw materials is required

Specifications for raw material analytical process is required

Required

Specifications and control tests on the finished product is required

Detail information of finished product analytical process is required

Required assay and related substance as per ICHQ2A and ICHQ2B

Required for 3 pilot batches

Complete information about product is required

Required as per ACTD guidelines

Required for Primary and secondary packing

Required as per climatic zone and ICH Guidelines for 3 batches

Zone IVb

Atleast 03 batches for accelerated and 03 batches for real time stability study

$40^{\circ} \mathrm{C} \pm 2{ }^{\circ} \mathrm{C} / 75 \% \pm 5 \% \mathrm{RH}$

$30^{\circ} \mathrm{C} \pm 2 \mathrm{C} / 70 \% \pm 5 \% \mathrm{RH}$

No specific requirement

General exempted for generics

General exempted for generics
No specific requirement

Required as per WHO \&GMP guidelines

Required if CPP is not available

Required as per WHO format \& applicant shall fill in form BPFK 412.2

Required as per country specific

Specific information as per GMP is required

Required with detail information about the supplier

Not Required

All bioequivalence study of product is required

Required as per ACTD format

Required copy of Master BMR or Complete BMR

Details of IPQC and specifications for quality assurance of the product is required

Required, on 3 pilot or commercial batches

Specifications and test methods for raw materials is required

Specifications for raw material analytical process is required

Not required for pharmacopeia materials

Specifications and control tests on the finished product is required

Detail information of finished product analytical process is required

Required assay and related substance as per ICHQ2R1

Required, for at least two pilot batches

Required as supporting document

Required as per ACTD guidelines

Specification including description of primary packaging components

Required as per climatic zone \& ICH Guidelines for 3 batches

Zone II \& IVb

Atleast 02 batches for accelerated and 03 batches for real time stability study

$40^{\circ} \mathrm{C} \pm 2{ }^{\circ} \mathrm{C} / 75 \% \pm 5 \% \mathrm{RH}$

$30 \mathrm{C} \pm 2 \mathrm{C} / 75 \% \pm 5 \% \mathrm{RH}$

No specific requirement

General exempted for generics, applicable for schedule poison drug

General exempted for generics.

\section{Drug Registration Process and Approval System of} Cambodia (3)

\subsection{Regulatory Agency}

Department of Drugs and Food under, Ministry of Health, Cambodia (MOH)

Department of Drugs and Food under the $\mathrm{MOH}$ is responsible for the quality and control of pharmaceuticals. 
The Department is composed of five bureaus each with their own speciality, three of which are:

- The Narcotic Control and Pharmaceutical Trade Bureau

- The Drug Regulation Bureau

- The Registration and Cosmetics Bureau

\subsection{Licensing Regulation in Cambodia}

A person who wish to sell, or import drug into Cambodia have to license registered with the $\mathrm{MOH}$ Department of Drugs and Food Administration through the Registration and Cosmetics Bureau. Import licence can be issued within one week after submission of required document and application form. Import licence is valid for six months from the date of approval.

\subsection{Drug Registration Process}

Applicants: Only Pharmacist or a Pharmaceutical company is qualified to apply for product registration.

Manufacturing Plant: GMP Compliance Flow chart of drug review process is shown in Figure 2.

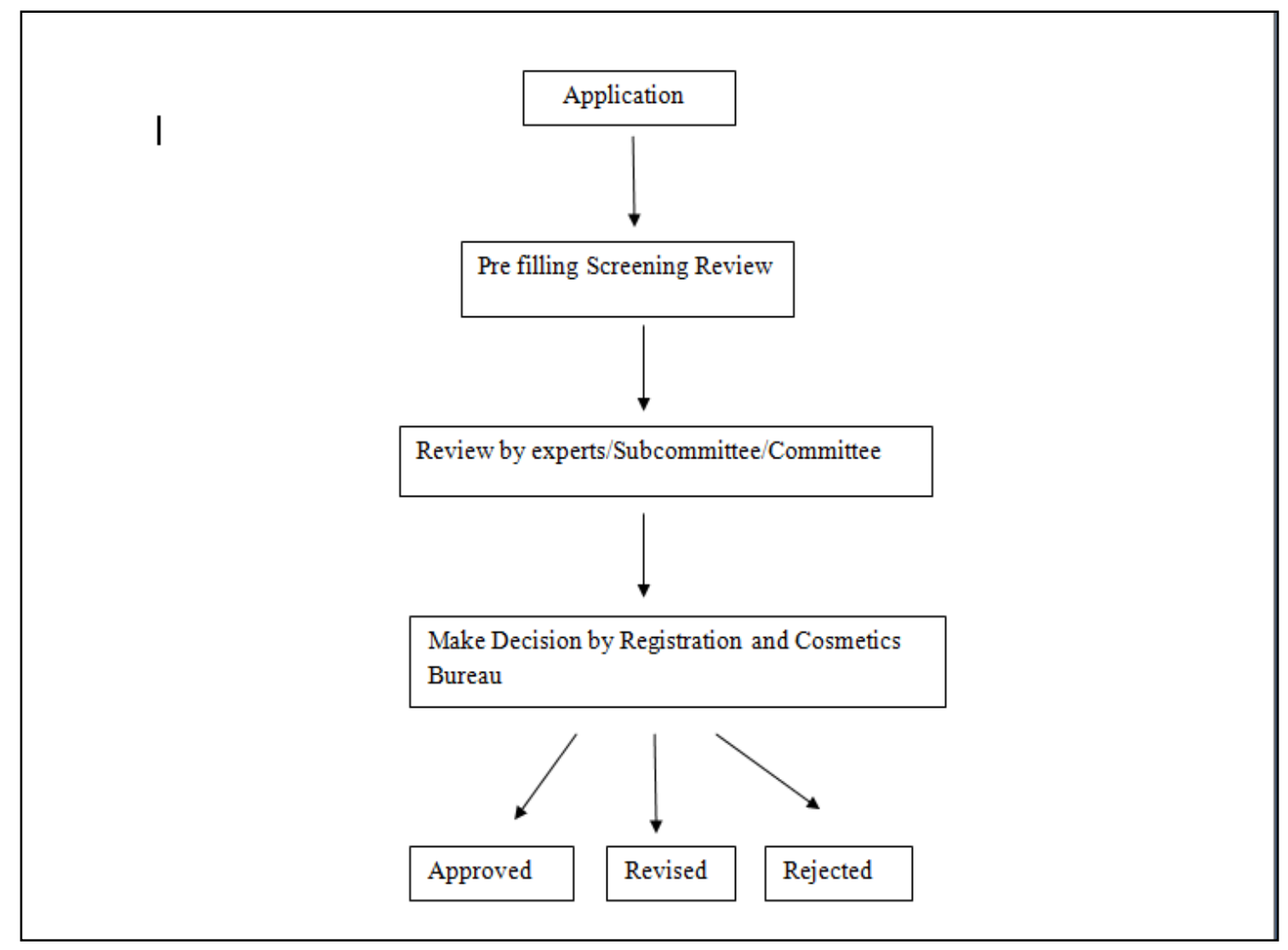

Figure 2: Flow chart of Drug Review Process for Cambodia (3)

\subsection{Review Period of Generic Drug Registration}

There are no timelines regarding the review period and no information regarding notification of successful registration.

\subsection{Review Fees of Generic Drug Registration}

No fees are charged for the Registration.

\subsection{Labelling Requirement in Cambodia}

The law and regulation on labelling are stipulated as per the law on the Management of Quality and Safety of Products and Services.

Labelling requirements are as follows:

- Name of product

- Details of ingredients

- Composition

- User's guidelines (direction for use)

- Manufacturing Date

- Expiry Date
- $\quad$ Producer name and address

- Quantity

- Batch number

Package inserts also required and it's contain the product name, active ingredients, indications, instructions for use, including warnings, precautions, adverse drug reaction, and contraindication, dosage and storage information. All labelling requirements must be in Khmer or English.

\section{Conclusion}

From the study it was found that due to variation in regulatory requirement in various countries it is a major challenge for pharmaceutical companies to register their pharmaceutical products. For pharmaceutical companies in order to develop a drug formulation which can be simultaneously submitted in numerous countries for approval at the same time is difficult. Therefore, continuous process of harmonization is carried out all over the world to overcome this problem. It gives a brief information about the regulatory requirements for 
registration of pharmaceutical Product from the comparison study of Cambodia \& Malaysia. It can be concluded that the industry should target on submission or registration of pharmaceutical product at different countries depending on their stability, regional documents and other country specific documents.

\section{Acknowledgments}

The authors are thankful to college management for providing the equipment and the facility and IJDRA journal for publishing the article.

\section{Conflict of interest}

The authors declare no conflicts of interest.

\section{References}

1. ASEAN Common Technical Dossier (ACTD) [Internet] ASEAN; 2016 Dec [cited 2017 Apr 20]. Available from: http://asean.org/storage/2017/03/68.-December-2016ACTD.pdf

2. Association of Southeast Asian Nations. The founding of ASEAN [Internet] ASEAN; 1997 [cited 2017 Apr 21]. Available from: http://asean.org/asean/about-asean/history/

3. Department of Drugs and Food [Internet] Cambodia[cited 2017 Mar 30] Available from: https:// www.ddfcambodia.com

4. National Pharmaceutical Regulatory Agency [Internet] Malaysia: NPRA; 2018 [cited 2018 Jan 10]. Available From: http://npra.moh.gov.my/en/

5. Flary et al. Comparison of Generic Drug registration requirements in ASEAN Countries. International Journal of Research in Pharmacy and Chemistry. 2015; 5(1): 145-9. 